\title{
Thermal maturity evaluation using Raman spectroscopy for oil shale samples of USA: comparisons with vitrinite reflectance and pyrolysis methods
}

\author{
Md. Golam Kibria ${ }^{1}$ - Souvik Das ${ }^{1} \cdot$ Qin-Hong Hu${ }^{1} \cdot$ Asish R. Basu ${ }^{1} \cdot$ Wen-Xuan $\mathrm{Hu}^{2} \cdot$ Subhadip Mandal ${ }^{3}$
}

Received: 30 March 2019 / Published online: 19 April 2020

(c) The Author(s) 2020

\begin{abstract}
Thermal maturity is commonly assessed by various geochemical screening methods (e.g., pyrolysis and organic petrology). In this contribution, we attempt to establish an alternative approach to estimating thermal maturity with Raman spectroscopy, using 24 North American oil shale samples with thermal maturity data generated by vitrinite reflectance $\left(\mathrm{VR}_{\mathrm{o}} \%\right)$ and pyrolysis $\left(T_{\max }\right)$-based maturity calculation $\left(\mathrm{VR}_{\mathrm{e}} \%\right)$. The representative shale samples are from the Haynesville (East Texas), Woodford (West Texas), Eagle Ford and Pearsall (South Texas) Formations, as well as Gothic, Mancos, and Niobrara Formation shales (all from Colorado). The Raman spectra of disordered carbonaceous matter (D1 and G bands separation) of these samples were directly obtained from the rock chips without prior sample preparation. Using the Gaussian and Lorentzian distribution approach, thermal maturities from VR were correlated with carbon G and D1. We found that the Raman band separation (RBS) displayed a better correlation for equivalent $\mathrm{VR}_{\mathrm{e}} \%$ than vitrinite reflectance $\mathrm{VR}_{\mathrm{o}} \%$. The $\mathrm{RBS}(\mathrm{D} 1-\mathrm{G})$ distance versus total organic carbon, free hydrocarbons from thermal extraction (S1), and the remaining hydrocarbon generating potential (S2) indicate that the RBS (D1-G) distance is also related to kerogen type. Data presented here from three methods of maturity determination of shale demonstrate that Raman spectroscopy is a quick and valid approach to thermal maturity assessment.
\end{abstract}

Keywords US shale $\cdot$ Raman spectroscopy $\cdot$ Vitrinite reflectance $\cdot$ Thermal maturity

\section{Introduction}

Geochemical evaluation is a critical aspect in evaluating source rock reservoir plays, specifically assessing the quantity, quality, and thermal maturity of sedimentary organic matter, and the implication for hydrocarbon generation, retention, and expulsion (Carvajal-Ortiz and Gentzis 2015). The thermal maturity assessment of source rock-reservoir rocks is routinely performed using pyrolysis $\left(T_{\max }\right)$ and

Edited by Jie Hao

Qin-Hong $\mathrm{Hu}$

maxhu@uta.edu

1 Department of Earth and Environmental Sciences, The University of Texas at Arlington, 500 Yates Street, Arlington, TX 76019, USA

2 Institute of Energy Sciences, Nanjing University, Nanjing 210093, China

3 Integrated Reservoir Solutions, Core Laboratories, Houston, TX 77040, USA vitrinite reflectance $\left(\mathrm{VR}_{\mathrm{o}} \%\right)$ data, though there are some other less common methods available, such as spore coloration index, solid bitumen reflectance, and spectral microfluorescence (e.g., Tissot 1984; Taylor et al. 1998).

Vitrinite is the remains of woody materials, commonly found in source rock-reservoir rocks, such as shales. Vitrinite reflectance $\left(\mathrm{VR}_{\mathrm{o}} \%\right)$ values increase with maturity (generally a function of depth) due to progressive changes in aromatization, condensation, and rearrangement of the vitrinite molecular structure (McCartney and Teichmüller 1972; Levine and Davis 1984; Carr 1999). Although this method is effective and widely used, it is expensive, labor-intensive, and dependent on an organic petrographer's judgment and experience that can significantly vary from person to person. Hackley and Cardott (2016) showed that the identification of vitrinite macerals versus certain other macerals, such as various types of solid bitumens, inertinite, and semi-fusinite, is challenging. Moreover, large variations $(20 \%-30 \%)$ in vitrinite reflectance of the same sample determined by different laboratories are a common problem. 
Another widely used maturity assessment method, pyrolysis, involves thermal decomposition of organic matter in an inert atmosphere (Peters 1986; Lafargue et al. 1998), yielding a temperature at the maximum rate of hydrocarbon generation $\left(T_{\max }\right)$ from pyrolysis of the $\mathrm{S} 2$ peak, along with other parameters, such as S1, S2, and S3. Additionally, a broad S2 peak in a pyrogram often compromises the accuracy and precision of the $T_{\max }$ value. Peters (1986) showed that when $S_{2} \leq 1 \mathrm{mg} \mathrm{HC/g}$ rock or the formation has a low TOC, the measured $T_{\max }$ value could be unreliable.

Raman spectroscopy is potentially a better technique for nondestructive, rapid, and precise maturity evaluation of hydrocarbon source rocks (Kelemen and Fang 2001; Marshall et al. 2012; Wilkins et al. 2014). In recent years, Raman spectroscopy has emerged as a indispensable useful method that provides information about the structural and chemical properties of carbon materials (e.g., Ferrari and Robertson 2000; Beyssac et al. 2002; Xie et al. 2008; Wilkins et al. 2014, 2015; Zhou et al. 2014; Schito et al. 2017; Sauerer et al. 2017; Schmidt et al. 2017; Khatibi et al. 2018; An et al. 2018; Hackley and Lünsdorf 2018). This method can also be used to study small, dispersed maceral grains that are difficult to study by other methods. This technique relies on peaks of carbon being resolved into Gaussian bands (Wilkins et al. 2014). The Raman spectrum of the organic carbon materials shows two primary bands: $G$ band (graphitic) near $\sim 1580 \mathrm{~cm}^{-1}$ and D band (disordered) around $\sim 1350 \mathrm{~cm}^{-1}$ (Tuinstra and Koenig 1970; BenyBassez and Rouzaud 1985; Gruber et al. 1994; Spötl et al. 1998; Kelemen and Fang 2001; Marshall et al. 2012; Schito et al. 2017). However, with an increase in thermal maturity, the $\mathrm{D}$ and $\mathrm{G}$ peaks shift toward lower and higher wavelengths, respectively. The distance between $\mathrm{G}$ and $\mathrm{D}$ peaks is called Raman band separation (RBS), and it has been used as a reliable maturity indicator (Kelemen and Fang 2001; Marshall et al. 2012; Wilkins et al. 2014; Sauerer et al. 2017; Schito et al. 2017).

Another important issue in recent works is that only the vitrinite reflectance is considered as the primary benchmark for correlation with Raman spectral data. The main problem is that the vitrinite reflectance itself shows a $10 \%-30 \%$ error, as the measurement is based on personal judgment. Recent studies such as Sauerer et al. (2017) conducted on 11 samples that are all type II organic matter, while Kelemen and Fang (2001) worked on shale samples of type II and Spötl et al. (1998) on type III organic matter (OM), respectively. The studies of Wilkins et al. (2015) and Schito et al. (2016) are based on core samples at different depths from a single well and were correlated with Raman spectroscopy, while Khatibi et al. (2018) concentrated only on Williston Basin, North Dakota. Our work examined Raman spectroscopybased maturity assessment on samples from several different basins across the USA (Table 1). Raman spectral data were compared with both vitrinite reflectance-based maturity and pyrolysis-derived equivalent reflectance maturity of the same samples. In contrast with other studies, we examine here the correlation of different Raman spectral parameters data with maximum, minimum, and average vitrinite reflectance thermal maturity and equivalent vitrinite reflectance (derived from pyrolysis experiments $T_{\max }$ value). Another unique aspect of our present study is that it focuses on the various types of kerogen materials-type II-III, type III, and type IV.

\section{Samples and methodologies}

\subsection{Samples}

Sixteen samples with known $\mathrm{VR}_{\mathrm{o}} \%$ and 21 samples with $\mathrm{VR}_{\mathrm{e}} \%$ were selected from multiple organic-rich mudstones, shale and chalk formations in active USA source rock-reservoir plays (Table 1). The age of these samples ranges from Late Devonian to Cretaceous. Samples were obtained as 10-20 g splits from mostly drill cores (sidewall plugs), other than Eagle Ford samples which were from outcrops. Cores were chipped into approximately $10-15 \mathrm{~mm}$ size cube pieces for the Raman spectroscopy analyses. The powdered shale sample fractions $(<75 \mu \mathrm{m})$ were used to determine TOC using both Shimadzu TOC-VWS wet chemical total organic carbon analyzer at the University of Texas at Arlington, USA, and a Leco CS-200 carbon/sulfur analyzer in Nanjing University, China. The pyrolysis $(<75 \mu \mathrm{m})$ and vitrinite reflectance data (core chips) were obtained from external laboratories, as described below.

\subsection{Pyrolysis and organic richness}

Pyrolysis was performed on an OCE-II oil-gas evaluation workstation following Chinese Technical Standard GB/T 18602-2012 (SAC 2012) at the China University of Geosciences in Wuhan. Previous work has explained in detail about different pyrolysis apparatuses-their operations, measured parameters, potential pitfalls, and applications to petroleum exploration (Behar and Pelet 1985; Espitalié 1986; Peters and Cassa 1994; Lafargue et al. 1998; Cheshire et al. 2017). The OCE-II oil-gas evaluation workstation performs temperature-programmed heating to (1) thermally distil "free" or adsorbed hydrocarbons (S1 peak) from the sample, (2) pyrolyze the kerogen to produce hydrocarbons (S2 peak) in a second oven, and (3) obtain residual organic carbon content in $\mathrm{mg} / \mathrm{g}$ (S4 unit mass) of hydrocarbon source rock after pyrolysis. This instrument is not equipped with the S3 measurement unit which can detect unit mass of released carbon dioxide $(\mathrm{mg} / \mathrm{g})$ from thermal breakdown of kerogen. 
Table 1 Samples depth, location, formation name, age, lithology, and maturity

\begin{tabular}{|c|c|c|c|c|c|c|c|c|c|}
\hline No. & Sample ID & Depth, m & Location & Formation & Age & Lithology & $\mathrm{VR}_{\mathrm{o}} \%$ & $\begin{array}{l}\text { Equiva- } \\
\text { lent } \\
\mathrm{VR}_{\mathrm{e}} \%\end{array}$ & RBS, $\mathrm{cm}^{-1}$ \\
\hline 1 & TX W-3912 & 3912.11 & & & & & & 0.96 & $259.06 \pm 2.17$ \\
\hline 2 & TX W-3930 & 3930.70 & Pecos Co., TX & Woodford & Late Devonian & Shale/mudrock & $\begin{array}{c}1.17 \pm 0.05 \\
(N=31)\end{array}$ & 1.32 & $260.34 \pm 3.07$ \\
\hline 3 & TX W-3941 & 3941.67 & & & $\begin{array}{l}\text { Early Missis- } \\
\text { sippian }\end{array}$ & & & 1.10 & $259.86 \pm 2.54$ \\
\hline 4 & TX W-3955 & 3955.39 & & & & & & 0.87 & $256.10 \pm 3.01$ \\
\hline 5 & TX P-3987 & 3587.80 & $\begin{array}{l}\text { La Salle Co., } \\
\text { TX }\end{array}$ & Pearsall & $\begin{array}{l}\text { Lower creta- } \\
\text { ceous }\end{array}$ & Shale/mudrock & $\begin{array}{c}1.57 \pm 0.38 \\
(N=29)\end{array}$ & 0.98 & $249.41 \pm 3.78$ \\
\hline 6 & TX P-3609 & 3609.44 & & & & & & 1.12 & $256.48 \pm 3.22$ \\
\hline 7 & TX P-3635 & 3635.04 & & & & & & 1.16 & $256.10 \pm 2.77$ \\
\hline 8 & TX H-3346 & 3346.40 & & & & & & 1.41 & $262.03 \pm 3.64$ \\
\hline 9 & TX H-3374 & 3374.44 & $\begin{array}{l}\text { Harrison Co., } \\
\text { TX }\end{array}$ & Haynesville & Jurassic & Shale/mudrock & & 1.14 & $257.93 \pm 3.05$ \\
\hline 10 & TX H-3421 & 3421.68 & & & & & $\begin{array}{c}1.36 \pm 0.31 \\
(N=20)\end{array}$ & 1.68 & $263.77 \pm 3.17$ \\
\hline 11 & CO G-1797 & 1797.71 & & & & & & 0.89 & $256.49 \pm 1.86$ \\
\hline 12 & CO G-1798 & 1798.62 & $\begin{array}{l}\text { Montezuma } \\
\text { Co., CO }\end{array}$ & Gothic & Pennsylvanian & Shale/mudrock & $\begin{array}{c}1.40 \pm 0.14 \\
(N=18)\end{array}$ & 1.64 & $268.05 \pm 3.78$ \\
\hline 13 & CO G-1825 & 1825.45 & & & & & $\begin{array}{c}1.17 \pm 0.22 \\
(N=21)\end{array}$ & 0.92 & $243.26 \pm 2.06$ \\
\hline 14 & CO G-2664 & 2664.26 & & & & & $\begin{array}{c}1.03 \pm 0.24 \\
(N=22)\end{array}$ & 1.03 & $251.39 \pm 3.87$ \\
\hline 15 & CO M-725 & 725.42 & $\begin{array}{l}\text { Rio Blanco } \\
\text { Co., CO }\end{array}$ & Mancos & Cretaceous & Shale/Mudrock & $\begin{array}{c}0.37 \pm 0.13 \\
(N=18)\end{array}$ & 0.65 & $251.98 \pm 4.20$ \\
\hline 16 & CO M-727 & 727.25 & & & & & $\begin{array}{c}0.37 \pm 0.13 \\
(N=24)\end{array}$ & 0.51 & $241.87 \pm 1.79$ \\
\hline 17 & TX EF outcrop & & $\begin{array}{l}\text { Val Verde Co., } \\
\text { TX }\end{array}$ & Eagle ford & Cretaceous & & $\begin{array}{c}0.66 \pm 0.47 \\
(N=31)\end{array}$ & 0.49 & $236.28 \pm 1.36$ \\
\hline 18 & CO N-891 & 891.54 & & & & Chalk & $\begin{array}{c}1.68 \pm 0.66 \\
(N=16)\end{array}$ & 0.63 & $236.24 \pm 4.82$ \\
\hline 19 & CO N-910 & 910.74 & $\begin{array}{l}\text { Larimer Co., } \\
\text { CO }\end{array}$ & Niobrara & Cretaceous & Marl/Shale & $\begin{array}{c}1.83 \pm 0.49 \\
(N=20)\end{array}$ & 0.78 & $242.34 \pm 2.94$ \\
\hline 20 & CO N-932 & 932.69 & & & & Marl/Shale & $\begin{array}{c}1.56 \pm 0.88 \\
(N=25)\end{array}$ & 0.40 & $229.48 \pm 4.45$ \\
\hline 21 & CO N-936 & 936.96 & & & & Chalk & $\begin{array}{c}1.48 \pm 0.47 \\
(N=27)\end{array}$ & 0.76 & $247.81 \pm 1.73$ \\
\hline 22 & CO N-947 & 947.01 & & & & Marl & $\begin{array}{c}1.86 \pm 0.65 \\
(N=29)\end{array}$ & 0.76 & $251.67 \pm 1.36$ \\
\hline 23 & NM BS-2908 & 2908.71 & Lea Co., NM & 1st bone spring & Permian & Dolomite & $\begin{array}{c}0.63 \pm 0.21 \\
(N=28)\end{array}$ & 0.90 & $258.42 \pm 1.82$ \\
\hline 24 & NM BS-2919 & 2919.98 & & & & Sandstone & $\begin{array}{c}0.63 \pm 0.18 \\
(N=21)\end{array}$ & 0.80 & $260.34 \pm 2.73$ \\
\hline
\end{tabular}

TX Texas, $C O$ Colorado, $N M$ New Mexico, $W$ Woodford shale, $P$ Pearsall Shale, $H$ Haynesville shale, $G$ Gothic Shale, $E F$ Eagle Ford Shale, $N$ Niobrara Shale, $B S 1$ st bone spring shale

The $T_{\max }$ is estimated based on $\mathrm{S} 2$ peak temperature that coincides with the maximum generation of hydrocarbons. The total hydrocarbon potential of the sample is defined by $(\mathrm{S} 1+\mathrm{S} 2)$, the hydrogen index $(\mathrm{HI})=\mathrm{S} 2 / \mathrm{TOC}$, and production index $(\mathrm{PI})=\mathrm{S} 1 /(\mathrm{S} 1+\mathrm{S} 2)$. Other parameters obtainable from pyrolysis are the bitumen index (BI), defined as S1/TOC (Killops et al. 1998), and the quality index (QI) (S1 + S2)/TOC (Pepper and Corvi 1995). The equivalent vitrinite reflectance is deduced from $T_{\max }$ $\left({ }^{\circ} \mathrm{C}\right)$ using the following equation (Jarvie et al. 2001; Jarvie, 2012): $\mathrm{VR}_{\mathrm{e}} \%=\left[0.018 \times T_{\max }\right]-7.16$. A calculated 
estimation of the uncertainty in $T_{\max }$ based upon duplicate analyses of identical sample splits is $3-5{ }^{\circ} \mathrm{C}$ for samples with $\mathrm{S} 2$ values $>10 \mathrm{mg} \mathrm{HC} / \mathrm{g}$ rock, equivalent to an internal precision of $\pm 0.05-0.10$ for the estimated $\mathrm{VR}_{\mathrm{e}} \%$.

\subsection{Vitrinite reflectance measurements}

Vitrinite reflectance measurements were conducted at two places. The analyses performed at Nanjing University followed the procedure of SY/T 5124-2012 (2012) in China, using rock slices. For the measurements at GeoMark Research, the samples were prepared according to procedures described by the American Society for Testing and Materials (ASTM) as shown in D2798 and D7708 (ASTM 2015a, b; Hackley and Cardott 2016). Whole-rock samples were crushed to 20 mesh $(850 \mu \mathrm{m}$ or $0.85 \mathrm{~mm}$ size $)$ particle size. Ground particles were placed in specially designed plastic molds ( 1.5 inches or $3.3 \mathrm{~cm}$ in diameter) to mix with epoxy resin and hardener (ratio of 2:1), leaving it for hardening overnight. Sample grinding and polishing were performed using Buehler EcoMet/AutoMet 250 automated polishing equipment. The sample surface is scratch- and relief-free for reliable $\mathrm{VR}_{\mathrm{o}} \%$ measurements because poorly polished surfaces can lower the $\mathrm{VR}_{\mathrm{o}} \%$ values (Hackley and Cardott 2016). Reflectance in oil $\left(\mathrm{VR}_{\mathrm{o}} \%\right)$ and fluorescence analyses were performed using a Carl Zeiss Axio Imager A2m microscope. For each sample, at least 25-30 readings of $\mathrm{VR}_{\mathrm{o}} \%$ in different parts of the pellet were obtained. Each vitrinite reflectance value used in this study is the mean random reflectance as a percentage, as calculated from the arithmetic average of individual readings. The standard deviation is calculated as the square root of the variance and represents the spread of $\mathrm{VR}_{\mathrm{o}} \%$ values.

\subsection{Raman spectroscopy measurements}

Raman spectroscopic measurements were performed on the flat surface of rock chips with minimum sample preparation (such as level the surface to fit into the stage on Raman spectroscopy), with the aim to establish a fast and convenient thermal maturation determination method with minimal laboratory preparation and analysis. All data in this study were obtained with a Thermo Scientific DXRxi Raman imaging spectroscopy. Spectra were generated mainly using $10 \times$ and sometimes using $50 \times$ objectives, by monochromatic excitation with $532 \mathrm{~nm}$ wavelength laser dispersed by a fixed 900 lines/mm holographic grating. The laser spot size for analyses was $10 \mu \mathrm{m}$ using $10 \times$ objective and $2 \mu \mathrm{m}$ while using $50 \times$ objectives. The operating conditions were $1-5 \mathrm{~s}$ for spectral acquisition, $1-10$ accumulations, and $0.7-5 \mathrm{~mW}$ for laser power. Though the DXRxi Raman imaging microscope is calibrated through auto-alignment, $\mathrm{Si}\left(520.5 \mathrm{~cm}^{-1}\right.$ peaks) is used to check the calibration. The Raman spectra were obtained and processed using the OMNICxi Raman Imaging software.

Sometimes, carbonaceous matter does not produce useful Raman spectra because of the "fluorescence" effect, from the presence of certain organic matter types. The fluorescence effect depends upon the interaction between the laser and the organic materials being examined and is sensitive to acquisition time and laser power. To minimize this effect, statistically large amounts of data were generated from each sample under different operating conditions (e.g., scan time, laser power, and magnification) so that all the RBS data given in this manuscript are an average of 20 spectra collected from different positions of the same rock chip. Here, we did not differentiate maceral type for collecting different spectra.

\subsection{Curve fitting of Raman spectroscopy}

Raman spectra of highly disordered carbonaceous materials are affected by interference due to fluorescence caused by the presence of long-chain alkenes and aromatic compounds. The first step in the analysis of the spectra is the removal of the high fluorescence background by a baseline subtraction procedure. The baseline subtraction was performed using a third-order polynomial curve that best represents the real trend of the fluorescence in the most immature samples with high background. To avoid errors induced by differences in the spectral range considered by the subtraction, we fixed baseline points at 1100 and $1700 \mathrm{~cm}^{-1}$ for all spectra. Once the process was optimized, it must be then reproduced for the entire set of samples. Deconvolution and fitting of the Raman spectra were made using five peaks with mixed Gaussian/Lorentzian profiles and linear baseline correction (Origin 2017 software). No constraints were put on the peak parameters in the curvefitting procedure to allow an optimal fit to the measured spectra. We observed that the maximum difference resulting from baseline corrections was detected for the $\mathrm{D}$ band intensity, whose values tend to be higher by $10 \%-15 \%$. After removal of the background, the spectra were deconvoluted using Origin software. As the Raman spectra of organic matter $(\mathrm{OM})$ in diagenetic conditions show broad overlapping bands, and from the application of multiple curve-fitting solutions (Lünsdorf and Lünsdorf 2016; Lupoi et al. 2017, 2018; Jubb et al. 2018; Hackley and Lünsdorf 2018), we found that the best solution using the minimum number of components could be attained using a five-band deconvolution with a mixed Gaussian-Lorentzian band profile (Fig. 4). All spectra were split using the five-peak deconvolution procedure. The band positions, amplitudes (intensities), full width at half maximum (FWHM), and integrated areas of all peaks were extracted 
from the resulting curve fits. Although the 20 spectra for each sample showed significant ranges in the peak widths, intensities, and areas, the mean G and D1 band positions and the error estimations for $\mathrm{G}$ and $\mathrm{D} 1$ positions were determined with a $1 \sigma$ error ranges between 0 and $5 \mathrm{~cm}^{-1}$.

\section{Results}

\subsection{Pyrolysis and equivalent reflectance}

Table 2 shows TOC, S1, S2, kerogen type, $T_{\max }$ values, and calculated values, such as HI, BI, QI, and PI, from pyrolysis of 21 samples. The TOC value ranges between 0.74 and $7.8 \mathrm{wt} \%, \mathrm{~S} 1$ values are between 0.18 and $4.24 \mathrm{mg}$ $\mathrm{HC} / \mathrm{g}$ rock, and S2 values range around $0.18-10 \mathrm{mg} \mathrm{HC/g}$ rock (Table 2). Hydrogen index (HI) of these samples is between 12 and $891 \mathrm{mg} \mathrm{HC/g}$ TOC. The HI values are lower than $100 \mathrm{mg} \mathrm{HC} / \mathrm{g}$ TOC, suggesting that most of the samples are thermally mature to postmature.

Note that five Niobrara samples yield high S1, S2, HI and $(\mathrm{S} 1 / \mathrm{TOC}) \times 100$, and respective $T_{\max }$ values range between 419 and $440{ }^{\circ} \mathrm{C}$. Vitrinite reflectance equivalence from $T_{\max }$ is estimated as 0.40 to $0.78 \mathrm{VR}_{\mathrm{e}} \%$ (Table 1). Calculated PI values are within the range of 0.23-0.69. Based on the pyrolysis data, one sample had type I kerogen, three samples with type II-III kerogen, nine samples with type III kerogen and eight samples with type IV kerogen. The $T_{\max }$ versus HI cross-plot of pyrolysis data showed that half the samples are II-III and III type and thermally mature to the postmature window which represents an oilto-gas generation condition. Three samples are immature, and the rest of the samples show an inert state (Fig. 1). A graph of S2 versus TOC indicates a direct correlation as the $\mathrm{S} 2$ value increases with the TOC value (Fig. 2a). The $T_{\max }$ versus bitumen index (BI) and quality index (QI) shows that with an increase in $T_{\max }$ value, the value of BI and QI decreases (Fig. 2b, c). A cross-plot between TOC and QI, where QI is combining S1 and S2, shows slightly sifted no correlation between the amount of then TOC and S2QI (Fig. 2d).

\subsection{Vitrinite reflectance and thermal maturity}

Vitrinite maceral groups are organic matter derived from the woody tissue of post-Silurian vascular plants. The inertinite group maceral may have experienced combustion, oxidation, or another carbonization process (e.g., desiccation). Liptinite group macerals include primarily algal material or amorphous organic matter (bituminite) derived from algal or bacterial predecessors. In the present study, organic petrological analyses of 16 samples showed the presence and

Table 2 Geochemical characteristics of 21 samples derived from pyrolysis method

\begin{tabular}{|c|c|c|c|c|c|c|c|c|c|c|}
\hline No. & TOC, wt $\%$ & $\mathrm{~S} 1, \mathrm{mg} / \mathrm{g}$ & $\mathrm{S} 2, \mathrm{mg} / \mathrm{g}$ & $T_{\max },{ }^{\circ} \mathrm{C}$ & QI & $\mathrm{HI}$ & BI & PI & Kerogen & Formation \\
\hline 1 & 6.57 & 1.23 & 1.16 & 451 & 2.39 & 18 & 0.19 & 0.51 & IV & Woodford \\
\hline 2 & 3.03 & 1.00 & 1.96 & 471 & 2.96 & 65 & 0.33 & 0.34 & III & \\
\hline 3 & 5.69 & 0.99 & 1.87 & 459 & 2.86 & 33 & 0.17 & 0.35 & IV & \\
\hline 4 & 7.80 & 1.45 & 1.92 & 446 & 3.37 & 25 & 0.19 & 0.43 & IV & \\
\hline 5 & 1.09 & 0.44 & 0.46 & 452 & 0.90 & 42 & 0.40 & 0.49 & IV & Pearsall \\
\hline 6 & 3.75 & 1.56 & 2.02 & 460 & 3.58 & 54 & 0.42 & 0.44 & III & \\
\hline 7 & 1.94 & 1.02 & 1.15 & 462 & 2.17 & 59 & 0.53 & 0.47 & III & \\
\hline 8 & 2.42 & 0.53 & 0.51 & 476 & 1.04 & 21 & 0.22 & 0.51 & IV & Haynesville \\
\hline 9 & 3.32 & 0.18 & 0.44 & 461 & 0.62 & 13 & 0.05 & 0.29 & IV & \\
\hline 10 & 2.23 & 0.20 & 0.27 & 491 & 0.47 & 12 & 0.09 & 0.43 & IV & \\
\hline 11 & 0.98 & 0.52 & 0.23 & 447 & 0.75 & 23 & 0.53 & 0.69 & III & Gothic \\
\hline 12 & 1.56 & 0.72 & 0.44 & 489 & 1.16 & 28 & 0.46 & 0.62 & III & \\
\hline 13 & 2.14 & 1.37 & 0.35 & 449 & 1.72 & 17 & 0.64 & 0.28 & IV & \\
\hline 14 & 1.21 & 0.25 & 0.18 & 455 & 0.43 & 15 & 0.21 & 0.58 & III & \\
\hline 15 & 0.89 & 0.23 & 0.67 & 434 & 0.90 & 75 & 0.26 & 0.26 & III & Moncos \\
\hline 16 & 0.74 & 0.30 & 0.63 & 426 & 0.93 & 85 & 0.41 & 0.32 & III & \\
\hline 18 & 2.49 & 3.48 & 6.47 & 419 & 9.95 & 260 & 1.40 & 0.35 & II-III & Niobrara \\
\hline 19 & 3.61 & 4.24 & 10.00 & 433 & 14.24 & 277 & 1.17 & 0.30 & II-III & \\
\hline 20 & 0.74 & 1.94 & 6.59 & 420 & 8.53 & 891 & 2.62 & 0.23 & I & \\
\hline 21 & 1.80 & 1.90 & 4.72 & 440 & 6.62 & 262 & 1.06 & 0.29 & II-III & \\
\hline 22 & 3.35 & 2.47 & 8.29 & 440 & 10.76 & 247 & 0.74 & 0.23 & III & \\
\hline
\end{tabular}

$\mathrm{S} 1=$ "free" or adsorbed hydrocarbons, $\mathrm{S} 2=$ remaining hydrocarbon, $\mathrm{QI}=(\mathrm{S} 1+\mathrm{S} 2), \mathrm{HI}=(\mathrm{S} 2 \times 100 / \mathrm{TOC}), \mathrm{BI}=(\mathrm{S} 1 / \mathrm{TOC}), \mathrm{PI}=\mathrm{S} 1 /(\mathrm{S} 1+\mathrm{S} 2)$ 


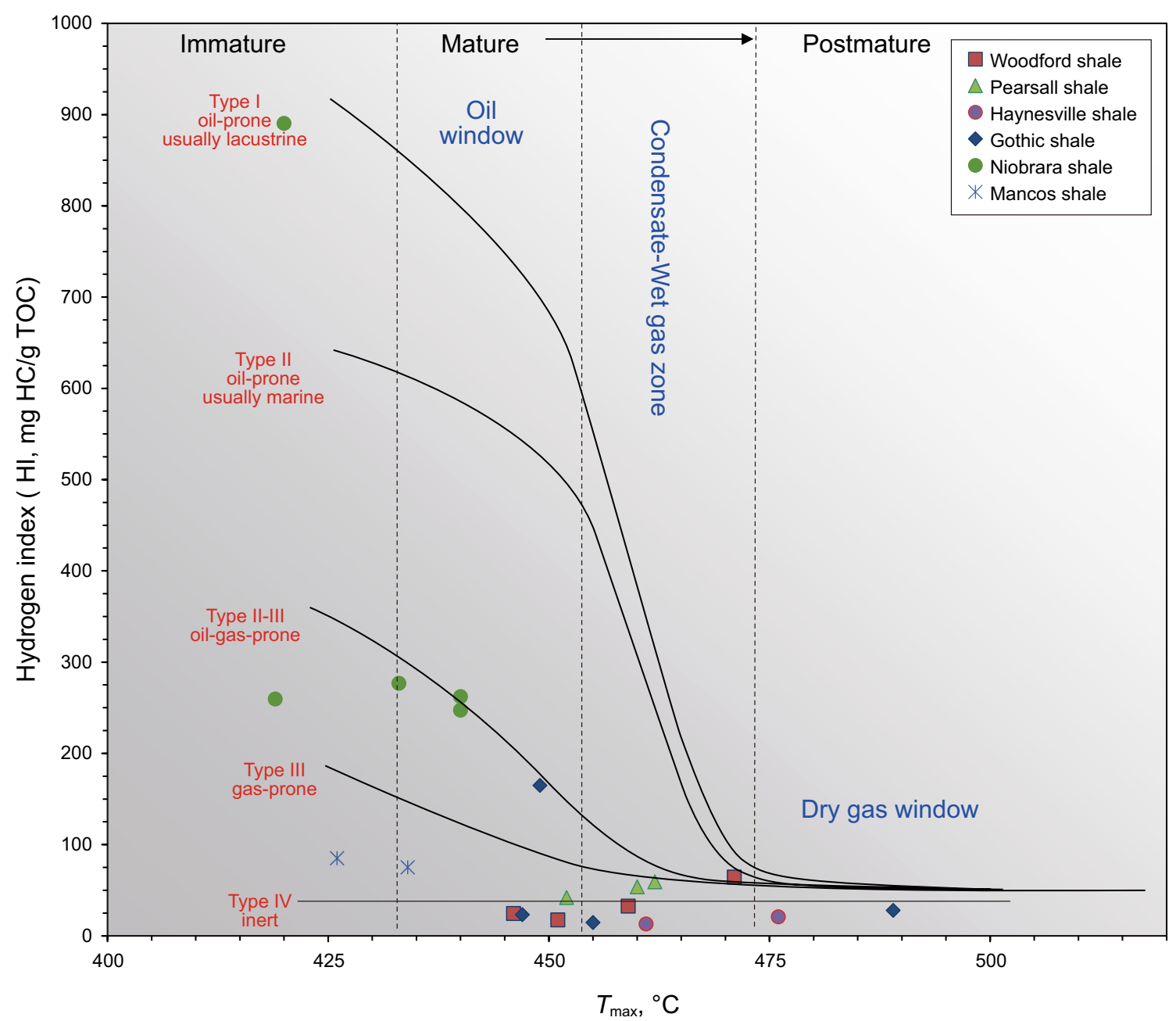

Fig. 1 Plot of hydrogen index (HI) versus pyrolysis $T_{\max }$ for the analyzed 21 samples, showing kerogen type and thermal maturity stages

distribution of all major maceral groups-bituminite, vitrinite, and inertinite (Fig. 3). In general, $0.2 \%-0.6 \% \mathrm{VR}_{\mathrm{o}}$ represents immature vitrinite, $0.7 \%-0.9 \% \mathrm{VR}_{\mathrm{o}}$ represents low gray vitrinite, $1 \%-1.6 \% \mathrm{VR}_{\mathrm{o}}$ suggests high gray vitrinite, and above $1.6 \% \mathrm{VR}_{\mathrm{o}}$ indicates inertinite (Hackley and Cardott, 2016). Vitrinite reflectance measurements from the shale samples show a broader distribution of different maceral groups. Here, some of the representative samples such as TX P-3987, TX EF outcrop, and CO N-910 indicate several types of maceral groups within their vitrinite counts (Fig. 3). The reported vitrinite reflectance value is an average of many (16-31) measurements of vitrinite reflectance.

\subsection{Raman spectroscopy and thermal maturity}

The described fitting procedure was carried out on all sample spectra. An example of fitting spectra (Sample 5: TX P-3987) is shown in Fig. 4 about the position and band names of carbonaceous material on Raman spectra. Best-fit results were achieved by considering $\mathrm{G}$ and $\mathrm{Dl}$ as purely Gaussian and D2, D3, and D4 as mixed Gaussian-Lorentzian functions. It is worth mentioning here that RBS is found as a more robust parameter than $\mathrm{G}$ and $\mathrm{D} 1$ band area ratio while comparing with equivalent reflectance $\left(\% \mathrm{VR}_{\mathrm{e}}\right)$. The efficacy of RBS with thermal maturity was also observed by Sauerer et al. (2017). The RBS versus vitrinite reflectance $\left(\% \mathrm{VR}_{\mathrm{o}}\right)$ shows a poor correlation suggesting a higher error in petrographic measurements.

\subsubsection{Correlation of Raman band separation (RBS) with maturity}

The D1 and G Raman bands represent processes occurring at different carbonization ranks. The D1 band shift toward lower wavelength can be assigned to the growth of larger aromatic clusters passing from disordered to ordered organic material (Ferrari and Robertson 2000). The Raman data plot of D1-G distance versus sample depth plot of 

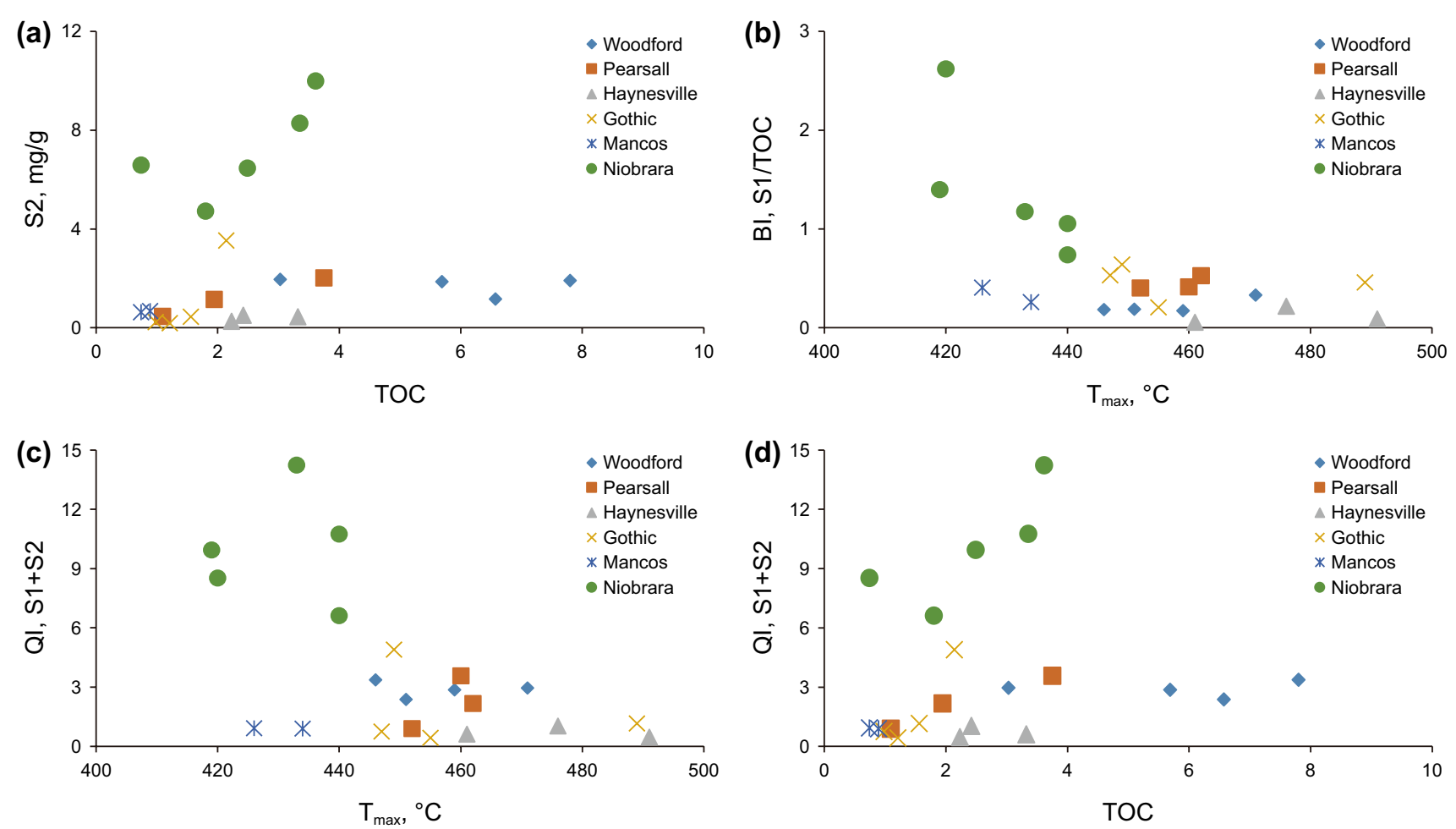

Fig. 2 Correlation between the measured parameters by pyrolysis: a $\mathrm{S} 2$ versus TOC; $\mathbf{b} T_{\max }$ versus BI (S1/TOC); $\mathbf{c} T_{\max }$ versus QI (S1+S2); d TOC versus $\mathrm{QI}(\mathrm{S} 1+\mathrm{S} 2)$
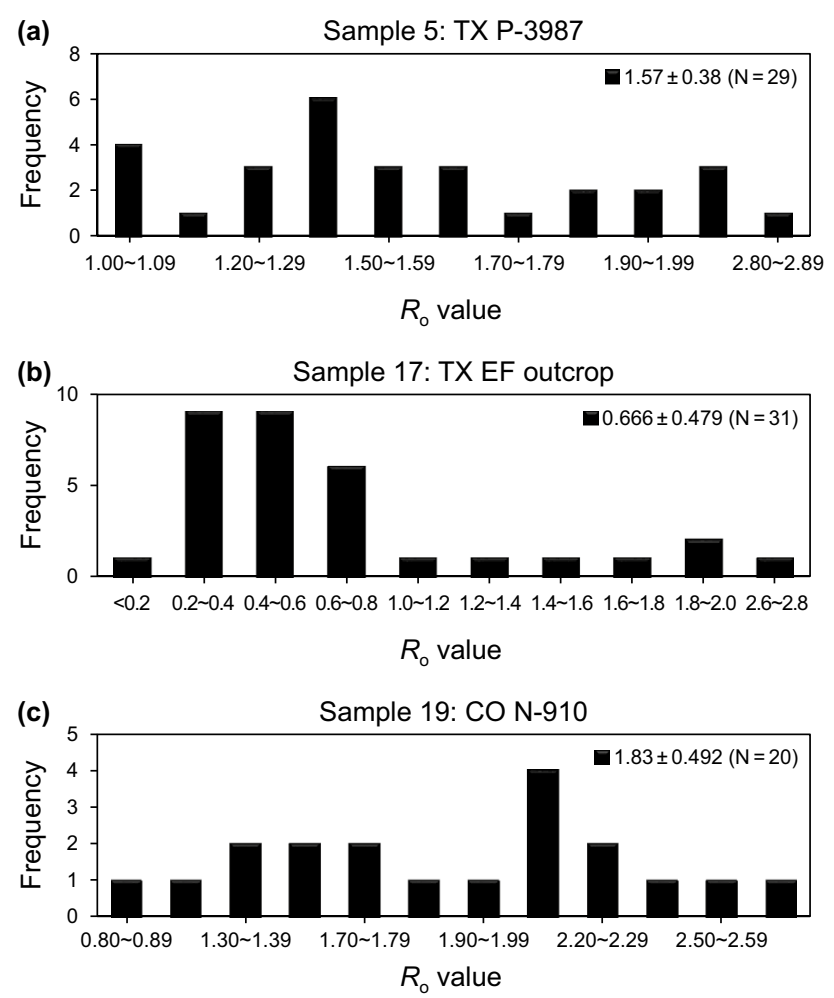

Fig. 3 Histograms of vitrinite reflectance from selected samples

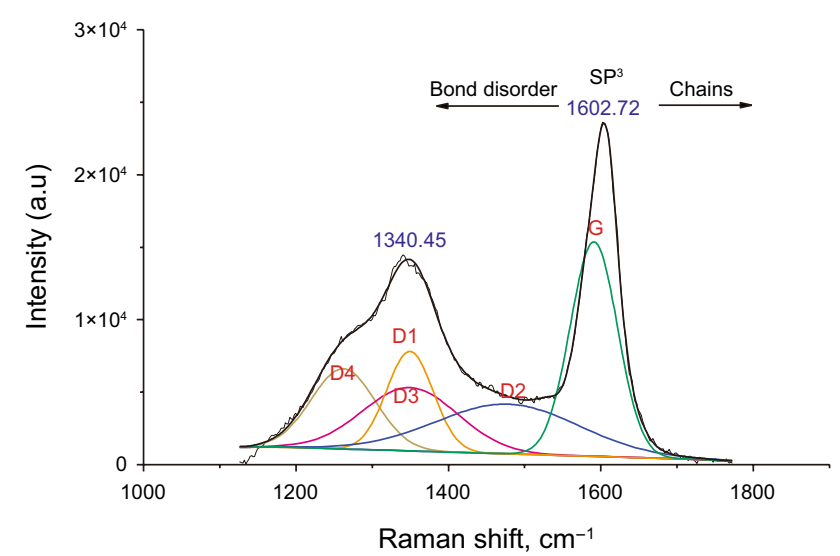

Fig. 4 Raman spectral characteristics of common five-band deconvolution outcome for an organic matter spectrum; $\mathrm{D}=$ disordered bands $(1,2,3,4)$ and $\mathrm{G}=$ graphitic band

organic shales in different basins shows an increase in RBS with sample depth $\left(R^{2}=0.38\right)$ (Fig. 5a), and this increment in RBS suggests the higher degree of thermal maturity. The RBS distance increases with depth from about 225 to $270 \mathrm{~cm}^{-1}$. When correlating all the Raman data with both vitrinite reflectance $\mathrm{VR}_{\mathrm{o}} \%$ and equivalent vitrinite reflectance $\mathrm{VR}_{\mathrm{e}} \%$, the higher shift of $\mathrm{G}$ position and lower shift of $\mathrm{D} 1$ position with vitrinite reflectance $\mathrm{VR}_{\mathrm{o}} \%$ shows 
RBS, $\mathrm{cm}^{-1}$
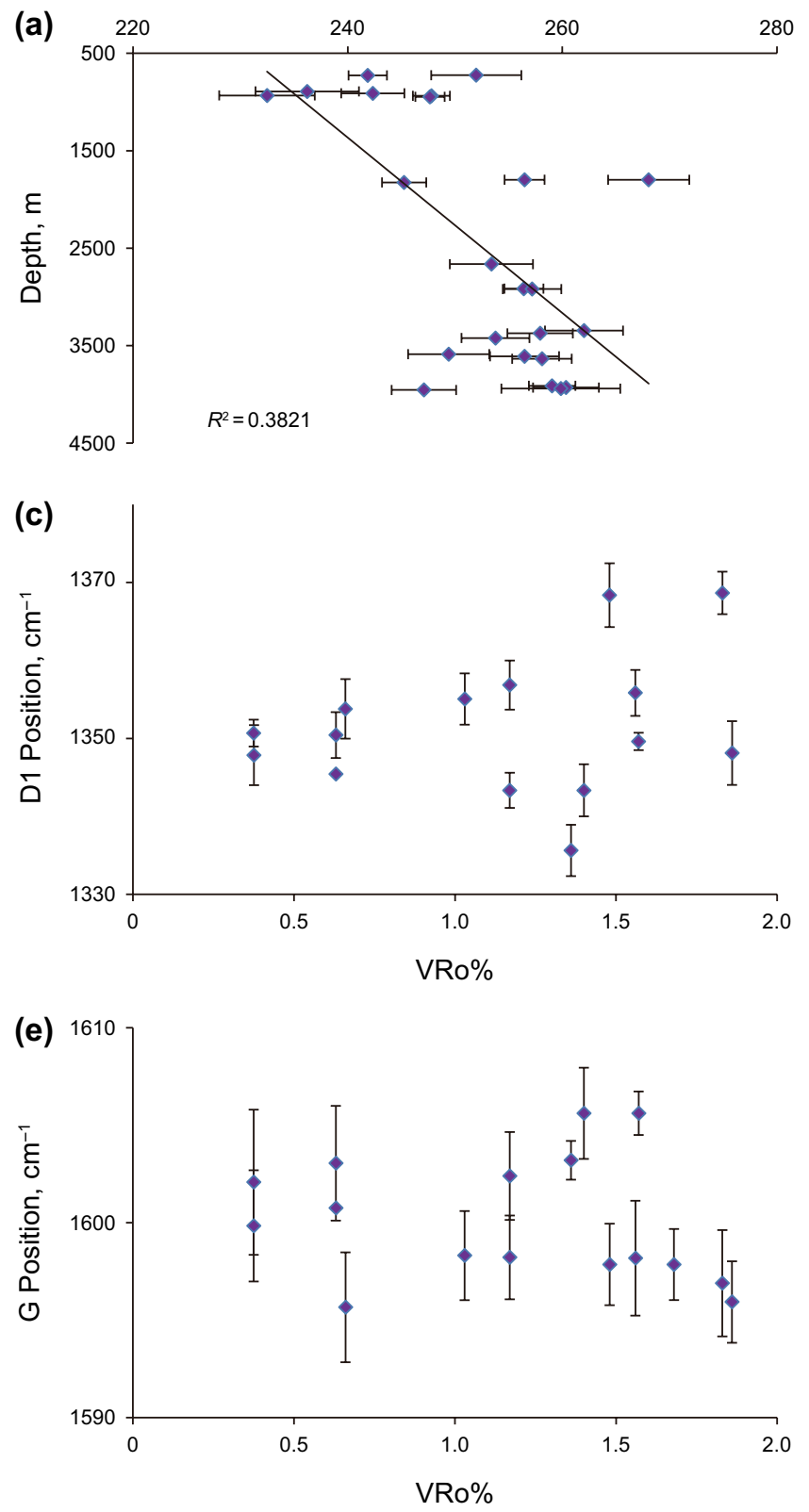

RBS, $\mathrm{cm}^{-1}$
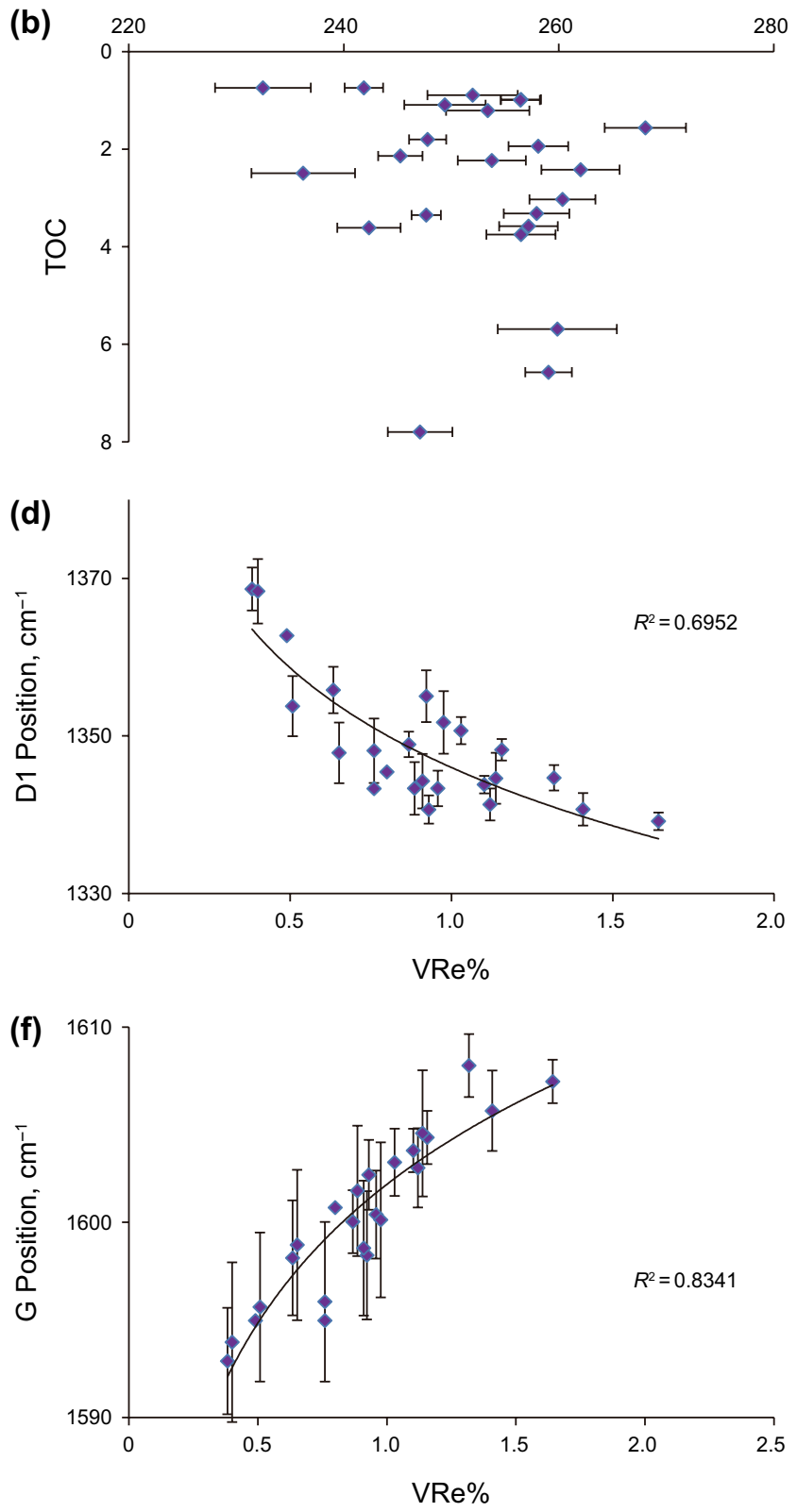

Fig. 5 Raman structural parameters correlated with depth, TOC, and known maturity: a RBS distance versus depth; b RBS distance versus TOC; $\mathbf{c} \mathrm{VR}_{\mathrm{o}} \%$ versus $\mathrm{D} 1$ position; $\mathbf{d} \mathrm{VR}_{\mathrm{e}} \%$ versus $\mathrm{D} 1$ position; $\mathbf{e} \mathrm{VR}_{\mathrm{o}} \%$ versus $\mathrm{G}$ position; $\mathbf{f} \mathrm{VR}_{\mathrm{e}} \%$ versus $\mathrm{G}$ position

a weak relationship (Fig. 5c, e). The D1 band position shifts toward lower values with the increase in $\mathrm{VR}_{\mathrm{e}} \%$ from about 1370 to $1330 \mathrm{~cm}^{-1}$ (Fig. 5d). Similarly, the G band position shows a shift from 1592 to $1608 \mathrm{~cm}^{-1}$ with an increase in thermal maturity (Fig. 5f). The data show a modest correlation for an increase in the RBS distance with equivalent vitrinite reflectance determined by the shift of D1 position toward lower wavenumber (Fig. 5d, $\left.R^{2}=0.70\right)$ and $\mathrm{G}$ position toward higher wavenumber position (Fig. 5f, $R^{2}=0.83$ ). This observation is similar for
RBS distance with maturity in other work (Ferrari and Robertson 2000; Kelemen and Fang 2001; Guedes et al. 2010; Liu et al. 2012; Lünsdorf and Lünsdorf 2016). Our data clearly show that vitrinite reflectance-based maturity does not show a good correlation with RBS, as emphasized by previous researchers (e.g., Khatibi et al. 2018).

Tuinstra and Koenig (1970) reported that a vertical intensity ratio between G and D1 bands (ID1/IG) is related to the in-plane crystallized size in disordered graphite and gave a weak proportional correlation against $T_{\max }$ in a range 
between 420 and $500{ }^{\circ} \mathrm{C}$. We observe that the intensity ID1/ IG ratio also has a weak correlation with the $T_{\max }$ value. Some researchers showed a significant correlation between G and D1 band intensity versus thermal maturity (Wilkins et al. 2014, 2015; Schito et al. 2017; Sauerer et al. 2017; Schmidt et al. 2017). However, this study does not show any significant correlation (Fig. 6). The Raman band intensity largely depends on the analytical condition, whereas the wavenumber position is independent of the analytical condition and better represents the structural ordered/disordered mode of matter (Matthews et al. 1999).

\subsubsection{Correlation of Raman band area and band separation against thermal maturity}

In this section, we use the distance and full width at half maximum (FWHM) of the D and G bands area to correlate with thermal maturity. Here, we use mainly two area ratios based on Raman spectra:

1. area ratio $1=\mathrm{D} 1 \mathrm{area} / \mathrm{G}$ area
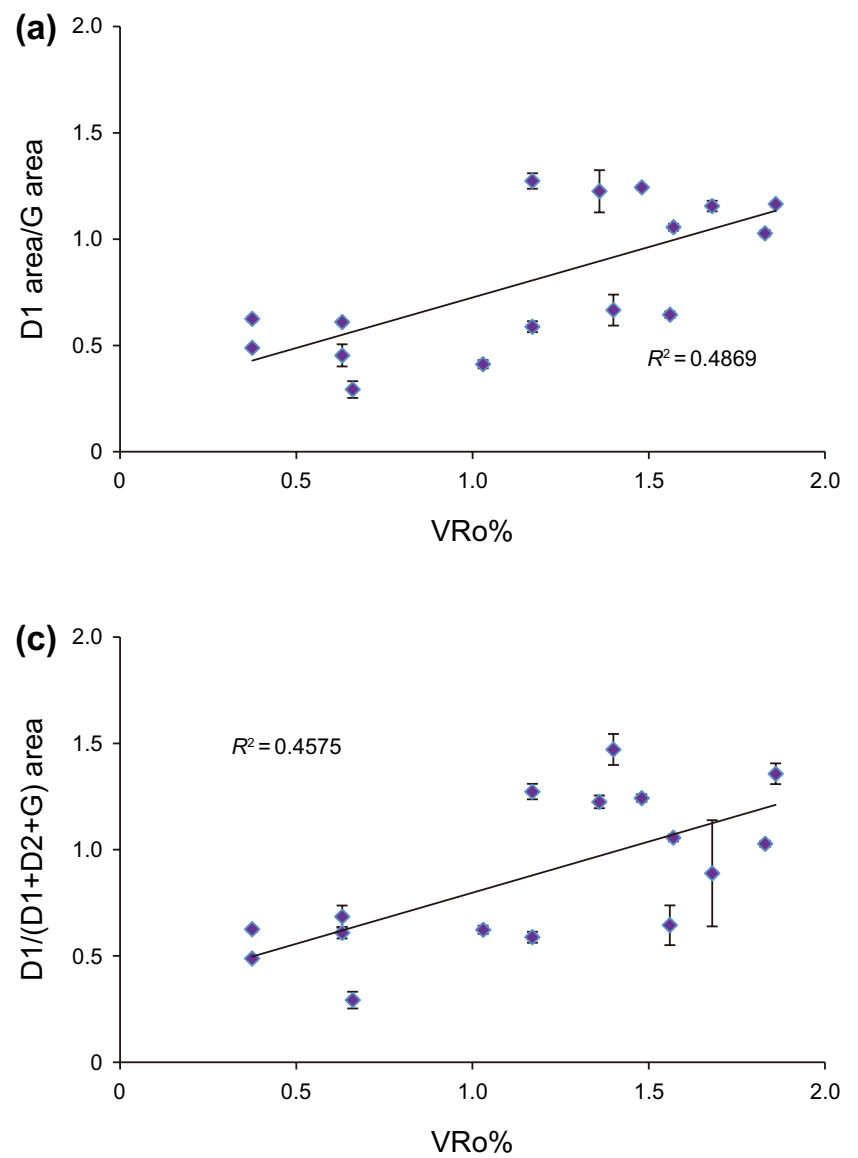

2. area ratio $2=\mathrm{D} 1$ area $/(\mathrm{D} 1+\mathrm{D} 2+\mathrm{G})$ area

These parameters are plotted against the maturity profile versus $\mathrm{VR}_{\mathrm{o}} \%$ and $\mathrm{VR}_{\mathrm{e}} \%$ (Fig. 6). $\mathrm{VR}_{\mathrm{o}} \%$ versus area ratio 1 (D1 area/G area) shows a moderate correlation $\left(R^{2}=0.49\right)$. In Fig. 6a, an increase in area1 ratio indicates an increase in thermal maturity. $\mathrm{VR}_{\mathrm{e}} \%$ versus area1 also shows a moderate correlation $\left(R^{2}=0.48\right)$ (Fig. $\left.6 \mathrm{~b}\right) . \mathrm{VR}_{\mathrm{o}} \%$ versus area ratio 2 [D1 area/(D1 $+\mathrm{D} 2+\mathrm{G})$ area] also shows a moderate correlation $\left(R^{2}=0.46\right)$ representing an increase in area ratio 2 proportionally related to the increase in $\mathrm{VR}_{\mathrm{o}} \%$ (Fig. 6c). $\mathrm{VR}_{\mathrm{e}} \%$ versus area ratio 2 shows a very poor correlation (Fig. 6d).

From Fig. $5 \mathrm{c}-\mathrm{f}$, it is observed that D1 wavelengths at peak maxima move to lower numbers and $G$ peak maxima move to higher wavelength maxima with progressively higher thermal maturity. The correlation between RBS distance and $\mathrm{VR}_{\mathrm{o}} \%$ and $\mathrm{VR}_{\mathrm{e}} \%$ demonstrates that the $\mathrm{VR}_{\mathrm{e}} \%$ data are more comparable with the Raman maturity method. The plot of $\mathrm{VR}_{\mathrm{o}} \%$ versus RBS distance shows a weak correlation (Fig. 7a). This suggests that the RBS distance and $\mathrm{VR}_{\mathrm{o}} \%$ are only poorly proportional because the increase in RBS
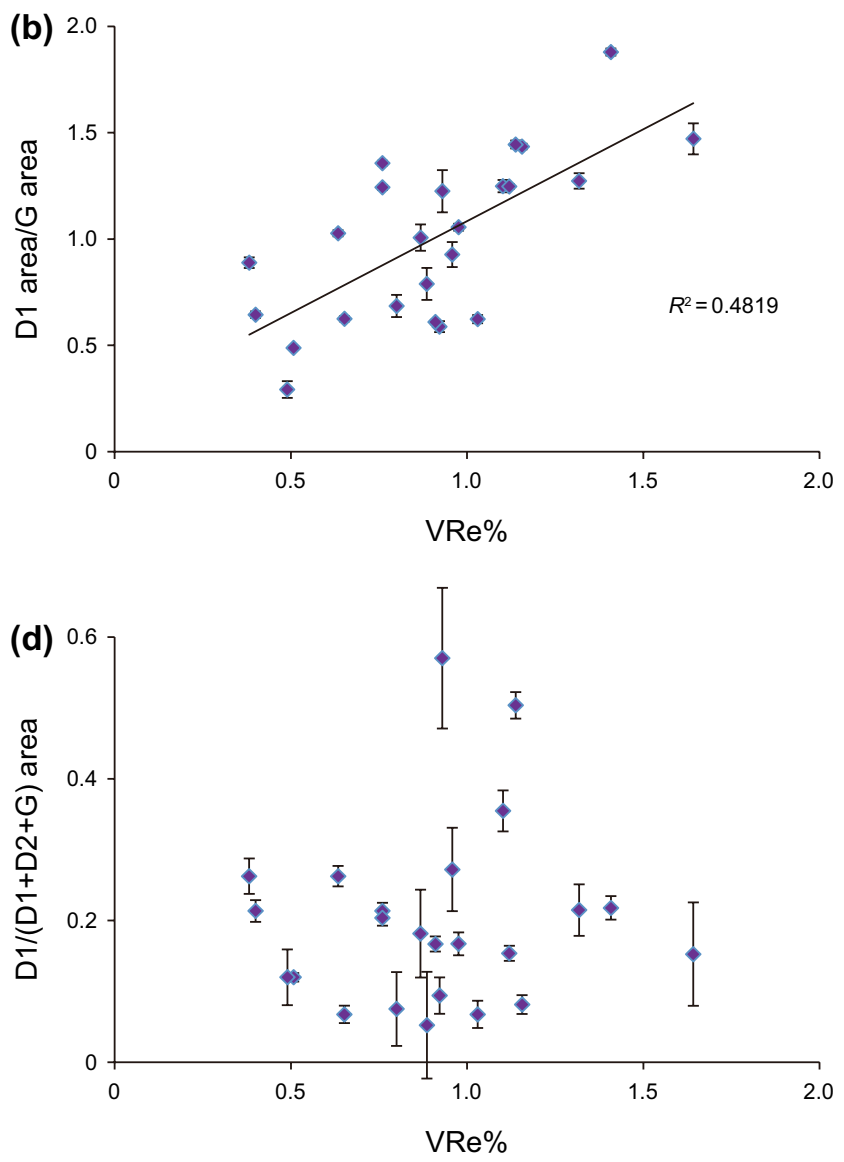

Fig. 6 Relationship between Raman structural parameters, different deconvolution band correlation as a function of known maturity: a vitrinite reflectance $\mathrm{VR}_{\mathrm{o}} \%$ versus area ratio 1 ; $\mathbf{b}$ equivalent reflectance $\mathrm{VR}_{\mathrm{e}} \%$ versus area ratio 1; c vitrinite reflectance $\mathrm{VR}_{\mathrm{o}} \%$ versus area ratio 2 ; $\mathbf{d}$ equivalent reflectance $\mathrm{VR}_{\mathrm{e}} \%$ versus area ratio 2 

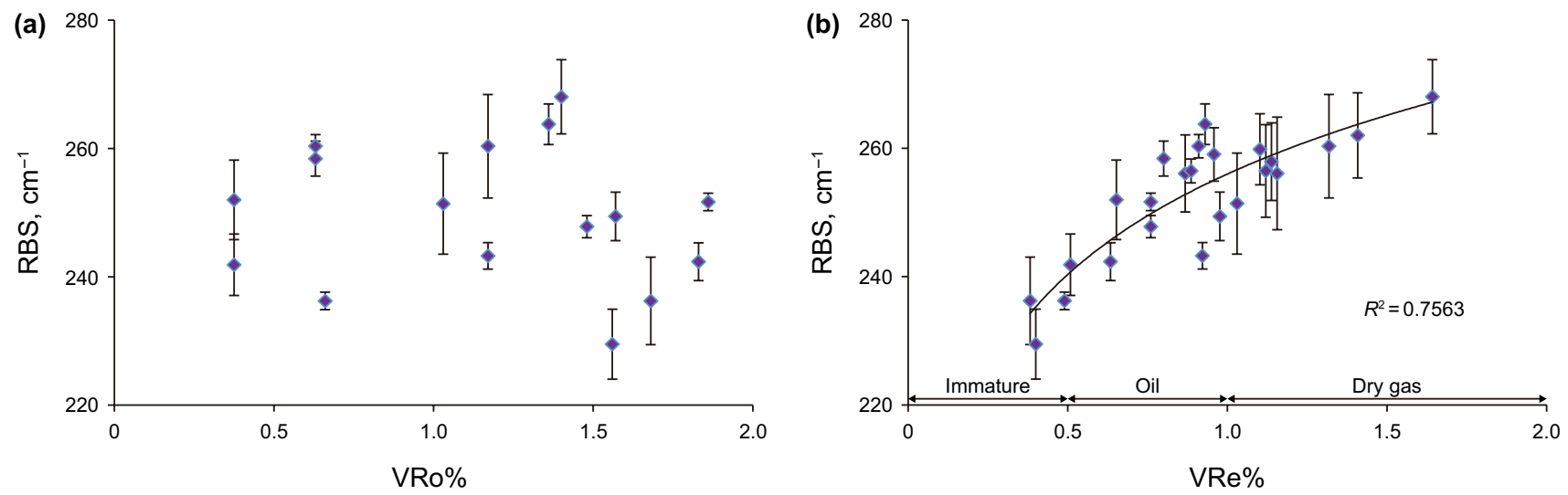

Fig. 7 Raman structural parameter plotted as a function of vitrinite reflectance $\left(\mathrm{VR}_{\mathrm{o}} \%\right)$ and equivalent vitrinite reflectance $\left(\mathrm{VR}_{\mathrm{e}} \%\right)$ : a $\mathrm{VR}_{\mathrm{o}} \%$ versus RBS distance; $\mathbf{b} \mathrm{VR}_{\mathrm{e}} \%$ versus RBS distance

distance corresponds only very generally to higher $\mathrm{VR}_{\mathrm{o}} \%$. In comparison, $\mathrm{VR}_{\mathrm{e}} \%$ versus RBS distance plot displays a good nonlinear correlation $\left(R^{2}=0.76\right)$ (Fig. 7b). The graph shows that the equivalent $\mathrm{VR}_{\mathrm{e}} \%$ maturity increases with higher RBS distances. This study indicates that based on the relationship between equivalent reflectance $\mathrm{VR}_{\mathrm{e}} \%$ and RBS distance, thermal maturity can be estimated by direct Raman spectroscopic analyses. Pyrolysis-based $T_{\max }$ value versus RBS distance represents a fair linear correlation $\left(R^{2}=0.73\right)$, with an increase between D1-G distance and $T_{\max }$.

\subsubsection{Correlation of RBS, pyrolysis, and kerogen type}

The relationship between RBS distance and pyrolysis data shows that RBS distance versus S1 (free remaining hydrocarbon) plot does not exhibit any direct relation. However, in general, it shows that small S1 values have large RBS distances. RBS distance versus S2 (remaining generating hydrocarbon potential) graph shows a similar trend, with a smaller S2 value indicating higher RBS distance.

Figure 8 shows the relationship of thermal maturity and RBS distance of different kerogen types. Vitrinite reflectance $\mathrm{VR}_{\mathrm{o}} \%$ versus kerogen-type RBS distance graph represents that there is a weak correlation between kerogen type and vitrinite reflectance (Fig. 8a). A plot of equivalent vitrinite reflectance $\mathrm{VR}_{\mathrm{e}} \%$ versus kerogen-type RBS distance represents an excellent linear correlation for some kerogen type. Kerogen type II-III signifies an excellent relationship with RBS distance $\left(R^{2}=0.98\right)$ (Fig. 8b). Kerogen type III and IV also show a good relationship with RBS distance. Equivalent vitrinite reflectance $\mathrm{VR}_{\mathrm{e}} \%$ maturity increases with higher RBS distance $\left(R^{2}=0.84\right)$ (Fig. 8b).
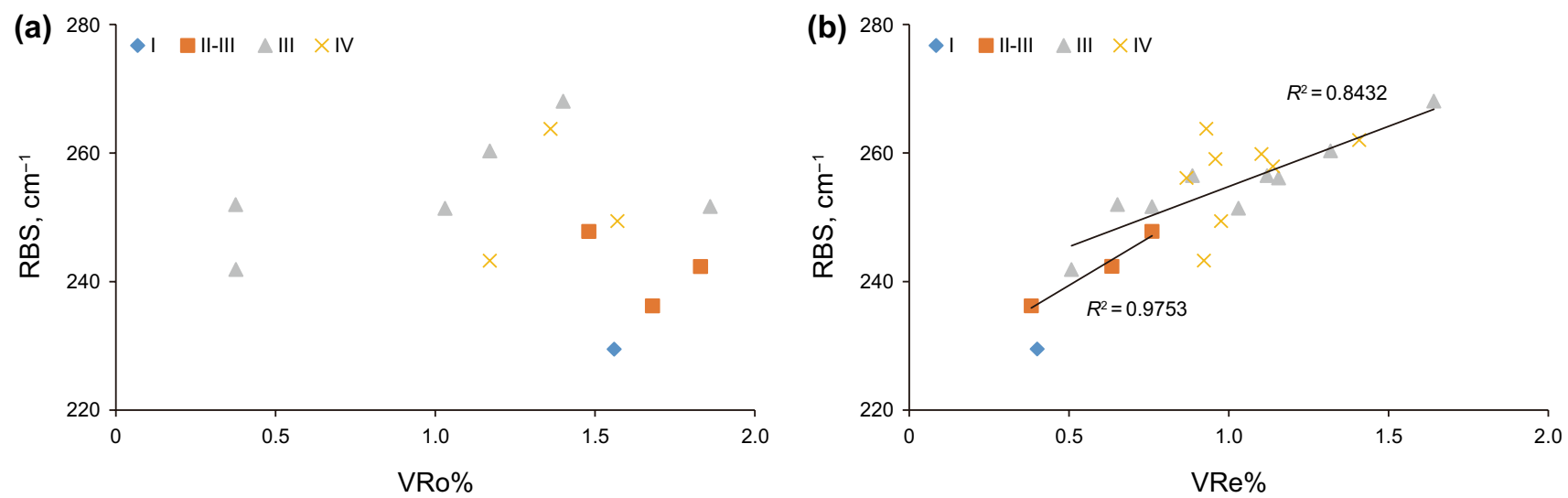

Fig. 8 Raman structural parameter correlations as a function of kerogen types: a vitrinite reflectance $\mathrm{VR}_{\mathrm{o}} \%$ versus RBS distance; $\mathbf{b}$ equivalent reflectance $\mathrm{VR}_{\mathrm{e}} \%$ versus $\mathrm{RBS}$ distance 


\section{Discussion}

\subsection{Pyrolysis and vitrinite reflectance}

The samples used for the present study show a marked difference in thermal maturity between vitrinite reflectance and equivalent reflectance from $T_{\max }$. A correlation of thermal maturity with Raman band separation indicates that an equivalent $\mathrm{VR}_{\mathrm{e}} \%$ is more appropriate for correlation purposes. It is essential to consider both $T_{\max }$ and vitrinite reflectance $\mathrm{VR}_{\mathrm{o}} \%$ values within a geological context for a proper understanding of maturity due to complex relations between paleoenvironment of deposition, organic matter types, and diagenetic development of the sedimentary formation (Snowdon 1995; Sykes and Snowdon 2002; Dembicki 2009; Carvajal-Ortiz and Gentzis 2015). However, Fig. 9 (vitrinite reflectance $\mathrm{VR}_{\mathrm{o}} \%$ vs. HI relationship) and Fig. 1 (equivalent $\mathrm{VR}_{\mathrm{e}} \%$ vs. HI) show that some samples have discrepancies in thermal maturity estimated by vitrinite reflectance and equivalent $\mathrm{VR}_{\mathrm{e}} \%$ methods. For example, sample $19(\mathrm{CO} \mathrm{N}-910) T_{\max }\left(433^{\circ} \mathrm{C}\right)$ values indicate that the organic matter is mature at the oil generation window (a conversion to equivalent $\mathrm{VR}_{\mathrm{e}} \%$ using the equation of Jarvie (2012) with an equivalent $\mathrm{VR}_{\mathrm{e}} \%=0.63 \%$ ), while the measured vitrinite reflectance $\mathrm{VR}_{\mathrm{o}} \%$ values on the same sample $19(\mathrm{CO} \mathrm{N}-910)\left(\mathrm{VR}_{\mathrm{o}} \%=1.83 \pm 0.492 \%\right)$ specify that the organic matter is postmature in the dry gas generation window.

Several researchers have shown that application of vitrinite reflectance to the determination of the thermal maturity of marine and lacustrine shales introduces frequent sources of error (Dennis 1974; Carvajal-Ortiz and Gentzis 2015). One of the critical issues is that the vitrinite reflectance scale is based on vitrinite, which is abundant and well preserved in coal. Due to the sedimentary reworking process of shale, the properties and volume of carbonaceous matter are different from coal. For this, the thermal maturity assessment

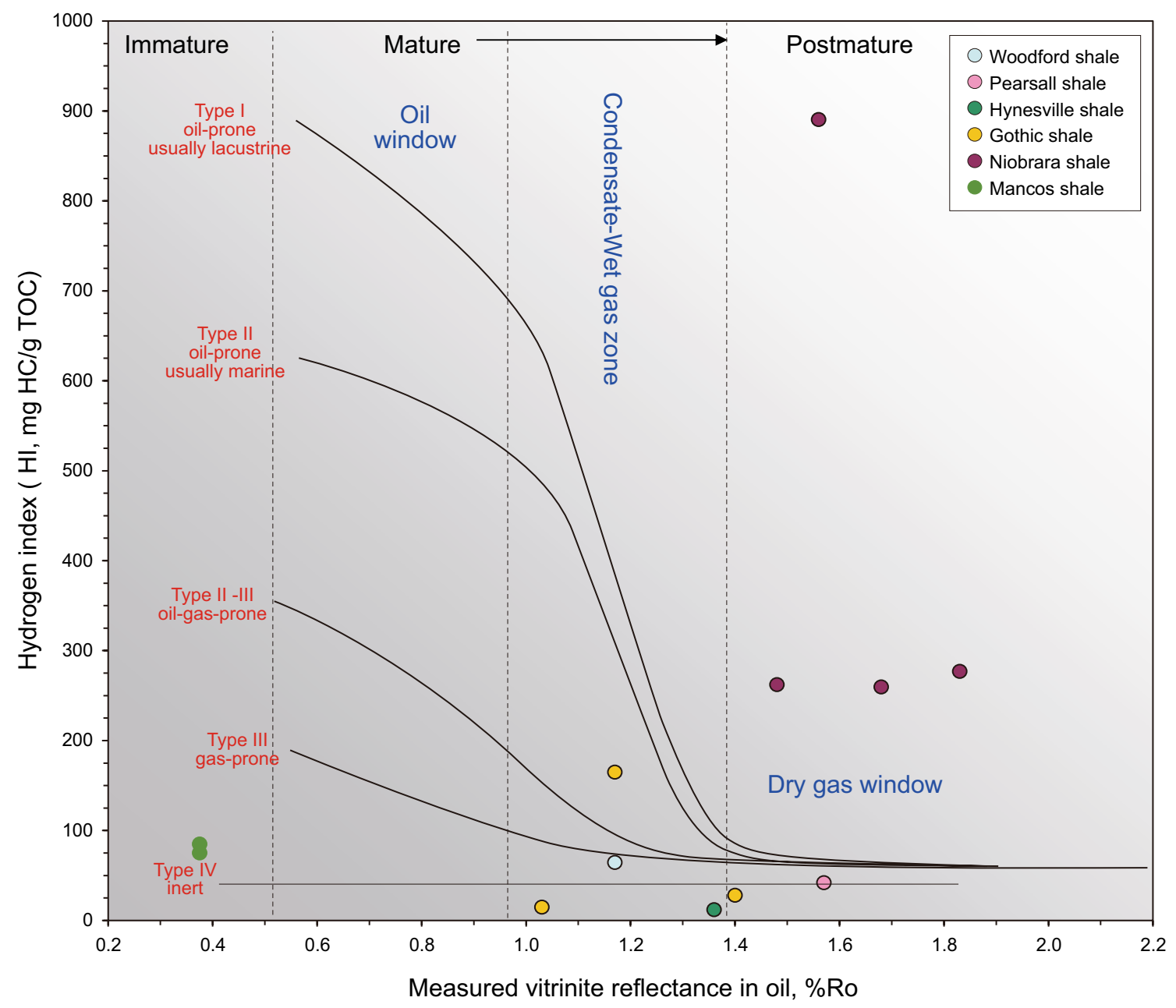

Fig. 9 Plot of hydrogen index (HI) versus measured vitrinite reflectance $\left(\mathrm{VR}_{\mathrm{o}} \%\right)$ for the analyzed samples, showing kerogen quality and thermal maturity stages 
method of shale should be different with respect to coal. Barker (1996) suggested a minimum of 20 maceral measurements for better statistical representation of constituent macerals. However, only 20 measurements can limit the validity of the calculated average value. For example, our sample 19 (Fig. 3) has 20 maceral observations. Meanwhile, there are no adequate data to outline a normalized distribution. Hackley and Cardott (2016) described that the most efficient method of the vitrinite reflectance estimation is to look not only at the mean value and the number of measurements, but also to the shape of the reflectance histogram, the spread of values, and photomicrographs of identified vitrinite.

\subsection{Raman band parameters, area ratios, and their application to dispersed organic matter}

With the aid of Raman spectroscopy, D1 and G band positions are controlled by the development of different types of carbonaceous material within the shale samples. The longchain aromatic clusters are transformed from disordered to ordered clusters when D1 bands shift toward lower wavenumbers (Fig. 5b; Ferrari and Robertson 2000). The change in Raman shift of D1 position toward a lower wavenumber (Fig. 5b) and $\mathrm{G}$ position toward higher wavenumber values controls the RBS distance (Fig. 5d), which clearly shows a direct relation with thermal maturity (Fig. 7b). This observation supports previous work on Raman band shifts (Ferrari and Robertson 2000; Kelemen and Fang 2001; Guedes et al. 2010; Liu et al. 2012; Schito et al. 2017). In this study, Raman spectral data fit well with $\mathrm{VR}_{\mathrm{e}}$ \% (i.e., $T_{\max }$ ), but not $\mathrm{VR}_{\mathrm{o}} \%$. Figure $7 \mathrm{~b}$ demonstrates that the RBS distance is a good parameter to use for determining thermal maturity.

In this work, the $\mathrm{G}$ band is fitted around $1603 \mathrm{~cm}^{-1}$ (Fig. 4) surrounded by a Lorentzian peak at $1610 \mathrm{~cm}^{-1}$ and a Gaussian D2 peak around $1500 \mathrm{~cm}^{-1}$. Heise et al. (2009) observed that the D2 band corresponds to the same vibration as the $\mathrm{G}$ band in small-size aromatic hydrocarbons. The $\mathrm{D}$ band area is decoupled to a central Lorentzian D band at $1340.45 \mathrm{~cm}^{-1}$, and two outer area Gaussian bands on $\mathrm{D} 4$, to the left of $\mathrm{D}$, and $\mathrm{D} 2$ to the right of $\mathrm{D}$, at 1250 and $1500 \mathrm{~cm}^{-1}$, respectively, that were assigned to identical vibrations of the $\mathrm{D}$ band but in small-size aromatic domains.

In this study, we have not observed a strong correlation between Raman intensity and maturity, but rather a weak correlation between D1/G area ratio and $\mathrm{VR}_{\mathrm{e}} \%$. Moreover, several spot analyses at different analytical conditions from a single sample show a wide variation in Raman spectral intensity. The low correlation coefficient in band intensity versus $T_{\max }$ suggests a lack of definite relationship, while Kelemen and Fang (2001) and Schito et al. (2017) found the most significant maturity relation with the G and D1 band intensity. Previous workers also noticed that the D2 and D3 band areas decrease with the increase in thermal maturity in shale ( $\mathrm{Li} 2007)$. The area ratio of D1 and G bands and parameters related to this ratio increase with the increase in thermal maturity (Fig. 6). Our results and earlier research show that an increase in structural ordering increases the Raman shift value of D1 band, and the Raman shift wavelength of G, D2, and D3 band decreases (Ferrari and Robertson 2000; Li 2007; Rebelo et al. 2016). Rebelo et al. (2016) showed that D4 and D bands have a similar pattern of vibrational modes and structural units for D2 and D3 bands for nanotube. Schito et al. (2017) observed similar coupled behavior for these bands at increasing temperatures. However, our study does not indicate any maturation trend for this complex band (D3 and D4). This result could be due to the different saturated and unsaturated hydrocarbon components in $\mathrm{OM}$ of the shale samples, or a variation of aromatic OM enrichment which results in different responses of the excitation bands with increasing thermal maturity. At experimental lower temperature (about $200-320{ }^{\circ} \mathrm{C}$ ), carbonaceous material displays band D4 from $s p^{3}$ to $s p^{2}$ shells around $1250 \mathrm{~cm}^{-1}$ (Lahfid et al. 2010), which is also observed in this study (Fig. 4). Lis et al. (2005) suggested that the heterogeneities in $\mathrm{C}-\mathrm{C}$ and $\mathrm{C}-\mathrm{H}$ bonds in aliphatic compounds at low maturity stages $\left(\mathrm{VR}_{\mathrm{o}} \%<1.5\right)$ are complex. In general, the changes in the Raman spectra are possibly due to a reduction in branched aliphatic chains, shortening of aliphatic chains, and formation of cyclic/aromatic compounds. Beyssac et al. (2002) observed the presence of two additional bands in the Raman spectrum of organic matter. One of the bands appears as a right end shoulder on the $\mathrm{G}$ band at approximately $1620 \mathrm{~cm}^{-1}$ if the sample is over-mature. In the present study, we do not have any postmature samples; the D2 band is a wideband existing at around $1500 \mathrm{~cm}^{-1}$.

\subsection{Thermal maturity and kerogen type correlation from Raman spectroscopy}

Estimated vitrinite reflectance equivalences of the samples were correlated with the Raman band separation ( $\mathrm{G}$ band shift minus D1 band shift), as described in the earlier sections, and were found to correlate with thermal maturity (e.g., Kelemen and Fang 2001; Schito et al. 2016; Sauerer et al. 2017; Cheshire et al. 2017). In this study, thermal maturity is determined using the equivalent vitrinite reflectance $\left(\mathrm{VR}_{\mathrm{e}} \%\right)$ versus RBS correlation from Raman measurements (Fig. 7b). Based on Fig. 7b correlation graph unknown samples RBS can convert to thermal maturity in the range of $0.5 \%-1.8 \% \mathrm{VR}_{\mathrm{e}}$. This correlation is based on type II-III, type III, and type IV kerogen samples. It is worth mentioning here that the type IV is not important for hydrocarbon generation. Types II-III represent a nearly perfect correlation for thermal maturity (Fig. 8b) with RBS $\left(R^{2}=0.98\right)$, while type III showed a good correlation $\left(R^{2}=0.84\right.$; Fig. $\left.8 \mathrm{~b}\right)$. This 
correlation can also be helpful to categorize kerogen types based on their RBS value trends for unknown samples. The most significant result of this study is that equivalent $\mathrm{VR}_{\mathrm{e}} \%$ has a much stronger correlation than vitrinite reflectance with thermal maturity, accompanying RBS increase with the increase in thermal maturity of the samples. The higher the maturity, the larger the RBS distance. Another important outcome of our study is that the Raman spectral intensity is not a useful parameter to estimate the thermal maturity.

\section{Conclusion}

Raman spectroscopy can be used as a method for the assessment of the thermal maturity of shale samples. The present study demonstrates that with an increase in thermal maturity, D1 and G peaks shift toward lower and higher wavelengths, respectively, which increases the Raman band separation (RBS). A total of 24 shale samples from different petroleum basins in the USA with a wide range of maturity (0.6-2 $\mathrm{VR}_{\mathrm{o}} \%$ ) were used to document that RBS has a good correlation $\left(R^{2}=0.76\right)$ with equivalent thermal maturity $\left(\mathrm{VR}_{\mathrm{e}} \%\right)$. Therefore, we can potentially gauge the thermal maturity of shales by this method of curve fitting for unknown samples using laser Raman spectroscopy. All these correlations show that with the aid of Raman spectroscopy alone, the maturation windows for immature kerogen, oil, wet gas, and dry gas can be evaluated for unknown samples. The present study suggests that the Raman-based thermal maturity can be better correlated with equivalent $\mathrm{VR}_{\mathrm{e}} \%$ instead of vitrinite reflectance $\mathrm{VR}_{\mathrm{o}} \%$. The conventional vitrinite reflectance $\left(\mathrm{VR}_{\mathrm{o}} \%\right)$ determination by petrography might produce a huge error. For this, we claim that the Raman spectroscopy-based maturity estimation is a better alternative. We also claim here that the RBS method can be helpful to determine the $T_{\max }$. Additionally, Raman spectra can be generated directly on drill cores and cutting chips without any sample preparation. Further data mining of Raman spectra collection from different basin samples will be needed to refine and establish a fast, less strenuous, and quantitative method for measuring thermal maturity for unconventional petroleum prospects.

Acknowledgements This research was partially supported by the Graduate Student Research Grants from the Gulf Coast Association of Geological Societies (GCAGS) and American Association of Petroleum Geologist (AAPG), by the University of Texas at Arlington and by the Pioneer Natural Resources. We are grateful to Harry Rowe, Robert Villegas, Jordan Bevers, Paul Huggins, Marvin Dunbar, and Scott Leaseburge for their assistance in sample procurement.

Open Access This article is licensed under a Creative Commons Attribution 4.0 International License, which permits use, sharing, adaptation, distribution and reproduction in any medium or format, as long as you give appropriate credit to the original author(s) and the source, provide a link to the Creative Commons licence, and indicate if changes were made. The images or other third party material in this article are included in the article's Creative Commons licence, unless indicated otherwise in a credit line to the material. If material is not included in the article's Creative Commons licence and your intended use is not permitted by statutory regulation or exceeds the permitted use, you will need to obtain permission directly from the copyright holder. To view a copy of this licence, visit http://creativecommons.org/licenses/by/4.0/.

\section{References}

An YX, Qu WJ, Yu PZ, Lü JG. The assembly of a composite based on nano-sheet graphene oxide and montmorillonite. Pet Sci. 2018;15(2):366-74. https://doi.org/10.1007/s12182-018-0216-3.

ASTM International. ASTM D2798-11a: standard test method for microscopical determination of the vitrinite reflectance of coal. West Conshohocken: ASTM International; 2015a, 5 p. https://doi. org/10.1520/d2798-11a.

ASTM International. ASTM D7708-14: standard test method for microscopical determination of the reflectance of vitrinite dispersed in sedimentary rocks. West Conshohocken, ASTM International; 2015b, 10 p. https://doi.org/10.1520/d7708-14.

Barker CE. A comparison of vitrinite reflectance measurements made on whole-rock and dispersed organic matter concentrate mounts. Org Geochem. 1996;24(2):251-6. https://doi.org/10.1016/01466380(96)00022-8.

Behar F, Pelet R. Pyrolysis-gas chromatography applied to organic geochemistry: structural similarities between kerogens and asphaltenes from related rock extracts and oils. J Anal Appl Pyrolysis. 1985;8:173-87. https://doi.org/10.1016/0165-2370(85)80024 -3 .

Beny-Bassez C, Rouzaud J. Characterization of carbonaceous materials by correlated electron and optical microscopy and Raman microspectroscopy. Scan Electron Microsc. 1985;1:119-32.

Beyssac O, Goffé B, Chopin C, Rouzaud J. Raman spectra of carbonaceous material in meta-sediments: a new geothermometer. J Metamorph Geol. 2002;20(9):859-71. https://doi.org/10.104 6/j.1525-1314.2002.00408.x.

Carr AD. A vitrinite reflectance kinetic model incorporating overpressure retardation. Mar Pet Geol. 1999;16(4):355-77. https://doi. org/10.1016/S0264-8172(98)00075-0.

Carvajal-Ortiz H, Gentzis T. Critical considerations when assessing hydrocarbon plays using Pyrolysis and organic petrology data: Data quality revisited. Int J Coal Geol. 2015;152:13-122. https:// doi.org/10.1016/j.coal.2015.06.001.

Cheshire S, Craddock PR, Xu G, Sauerer B, Pomerantz AE, McCormick D, et al. Assessing thermal maturity beyond the reaches of vitrinite reflectance and Pyrolysis: a case study from the Silurian Qusaiba formation. Int J Coal Geol. 2017;180:29-45. https://doi. org/10.1016/j.coal.2017.07.006.

Dembicki H Jr. Three common source rock evaluation errors made by geologists during prospect or play appraisals. AAPG Bull. 2009;93(3):341-56. https://doi.org/10.1306/10230808076.

Dennis MS. Interpretation of vitrinite reflectance measurements in sedimentary rocks and determination of burial history using vitrinite reflectance and authigenic minerals. Geol Soc Am. 1974;153:31.

Espitalié J. Use of $T_{\max }$ as a maturation index for different types of organic matter. Comparison with vitrinite reflectance. In: Burrus J, editor, Thermal modelling in sedimentary basins. Paris: Editions Technip; 1986, pp. 475-496.

Ferrari AC, Robertson J. Interpretation of Raman spectra of disordered and amorphous carbon. Phys Rev B. 2000;61(20):14095-107. https://doi.org/10.1103/PhysRevB.61.14095. 
Gruber T, Zerda TW, Gerspacher M. Raman studies of heat-treated carbon blacks. Carbon. 1994;32(7):1377-82. https://doi. org/10.1016/0008-6223(94)90125-2.

Guedes A, Valentim B, Prieto AC, Rodrigues S, Noronha F. MicroRaman spectroscopy of collotelinite, fusinite and macrinite. Int J Coal Geol. 2010;83(4):415-22. https://doi.org/10.1016/j. coal.2010.06.002.

Hackley PC, Lünsdorf NK. Application of Raman spectroscopy as thermal maturity probe in shale petroleum systems: insights from natural and artificial maturation series. Energy Fuels. 2018;32(11):11190-202. https://doi.org/10.1021/acs.energyfuel s.8b02171.

Hackley PC, Cardott BJ. Application of organic petrography in North American shale petroleum systems: a review. Int J Coal Geol. 2016;163:8-51. https://doi.org/10.1016/j.coal.2016.06.010.

Heise H, Kuckuk R, Ojha A, Srivastava A, Srivastava V, Asthana B. Characterization of carbonaceous materials using Raman spectroscopy: a comparison of carbon nanotube filters, single-and multi-walled nanotubes, graphitised porous carbon and graphite. J Raman Spectrosc. 2009;40:344-53. https://doi.org/10.1002/ jrs. 2120 .

Jarvie DM. Shale resource systems for oil and gas: part 2-shale-oil resource systems. AAPG Memoir. 2012;97:89-119. https://doi. org/10.1306/13321447M973489.

Jarvie DM, Claxton B, Henk B, Breyer J. Oil and shale gas from barnett shale, Ft. Worth Basin, Texas. AAPG National Convention, Denver, CO, USA June 3-6 2001 (AAPG Search and Discovery Article \#90906).

Jubb AM, Botterell PJ, Birdwell JE, Burruss RC, Hackley PC, Valentine BJ, et al. High microscale variability in Raman thermal maturity estimates from shale organic matter. Int J Coal Geol. 2018;199:1-9. https://doi.org/10.1016/j.coal.2018.09.017.

Kelemen S, Fang H. Maturity trends in Raman spectra from kerogen and coal. Energy Fuels. 2001;15:653-8. https://doi.org/10.1021/ ef0002039.

Khatibi S, Ostadhassan M, Tuschel D, Gentzis T, Bubach B, CarvajalOrtiz H. Raman spectroscopy to study thermal maturity and elastic modulus of kerogen. Int J Coal Geol. 2018;185:103-18. https ://doi.org/10.1016/j.coal.2017.11.008.

Killops SD, Funnell RH, Suggate RP, Sykes R, Peters KE, Walters C, et al. Predicting generation and expulsion of paraffinic oil from vitrinite-rich coals. Org Geochem. 1998;29(1-3):1-21. https://doi. org/10.1016/S0146-6380(98)00087-4.

Lafargue E, Marquis F, Pillot D. Pyrolysis 6 applications in hydrocarbon exploration, production, and soil contamination studies. Oil Gas Sci Technol. 1998;53:421-37. https://doi.org/10.2516/ ogst: 1998036

Lahfid A, Beyssac O, Deville E, Negro F, Chopin C, Goffé B. Evolution of the Raman spectrum of carbonaceous material in low-grade metasediments of the Glarus Alps (Switzerland). Terra Nova. 2010;22(5):354-60. https://doi.org/10.111 1/j.1365-3121.2010.00956.x.

Levine JR, Davis A. Optical anisotropy of coals as an indicator of tectonic deformation, Broad Top Coal Field, Pennsylvania. Geol Soc Am Bull. 1984;95(1):100-8. https://doi.org/10.1130/00167606(1984)95\%3C100:OAOCAA\%3E2.0.CO;2.

$\mathrm{Li} \mathrm{C}-\mathrm{Z}$. Some recent advances in the understanding of the pyrolysis and gasification behaviour of Victorian brown coal. Fuel. 2007;86:1664-83. https://doi.org/10.1016/j.fuel.2007.01.008.

Lis GP, Mastalerz M, Schimmelmann A, Lewan MD, Stankiewicz BA. FTIR absorption indices for thermal maturity in comparison with vitrinite reflectance R 0 in type-II kerogens from Devonian black shales. Org Geochem. 2005;36:1533-52. https://doi.org/10.1016/j. orggeochem.2005.07.001

Liu D, Xiao X, Tian H, Min Y, Zhou Q, Cheng P, Shen J. Sample maturation calculated using Raman spectroscopic parameters for solid organics: methodology and geological applications. Chin Sci Bull. 2012;58:1285-98. https://doi.org/10.1007/s11434-012-5535-y.

Lünsdorf NK, Lünsdorf JO. Evaluating Raman spectra of carbonaceous matter by automated, iterative curve-fitting. Int J Coal Geol. 2016;160:51-62. https://doi.org/10.1016/j.coal.2016.04.008.

Lupoi JS, Fritz LP, Hackley PC, Solotky L, Weislogel A, Schlaegle S. Quantitative evaluation of vitrinite reflectance and atomic $\mathrm{O} / \mathrm{C}$ in coal using Raman spectroscopy and multivariate analysis. Fuel. 2018;230:1-8. https://doi.org/10.1016/j.fuel.2018.04.172.

Lupoi JS, Fritz LP, Parris TM, Hackley PC, Solotky L, Eble CF, Schlaegle S. Assessment of thermal maturity trends in DevonianMississippian source rocks using Raman spectroscopy: limitations of peak-fitting method. Front. Energy Res. 5, Article 24, 2017. https://doi.org/10.3389/fenrg.2017.00024.

Marshall AO, Wehrbein RL, Lieberman BS, Marshall CP. Raman spectroscopic investigations of burgess shale-type preservation: a new way forward Raman spectroscopy of BST deposits. Palaios. 2012;27(5):288-92. https://doi.org/10.2110/palo.2011.p11-041r.

Matthews MJ, Pimenta MA, Dresselhaus G, Dresselhaus MS, Endo M. Origin of dispersive effects of the Raman D band in carbon materials. Phys Rev B. 1999;59(10):R6585. https://doi.org/10.1103/ PhysRevB.59.R6585.

McCartney JT, Teichmüller M. Classification of coals according to degree of coalification by reflectance of the vitrinite component. Fuel. 1972;51(1):64-8. https://doi.org/10.1016/00162361(72)90041-5.

Pepper AS, Corvi PJ. Simple kinetic models of petroleum formation. Part I: oil and gas generation from kerogen. Mar Pet Geol. 1995;12(3):291-319. https://doi.org/10.1016/02648172(95)98381-E.

Peters KE. Guidelines for evaluating petroleum source rock using programmed pyrolysis. AAPG Bull. 1986;70(3):318-29. https://doi. org/10.1306/94885688-1704-11D7-8645000102C1865D.

Peters KE, Cassa MR. Applied source rock geochemistry. In: Magoon LB, Dow WG, Editors, The petroleum system-from source to trap, vol. 60. AAPG Memoir; 1994, pp. 93-120.

Rebelo SL, Guedes A, Szefczyk ME, Pereira AM, Araújo JP, Freire C. Progress in the Raman spectra analysis of covalently functionalized multiwalled carbon nanotubes: unraveling disorder in graphitic materials. Phys Chem Chem Phys. 2016;18:12784-96. https://doi.org/10.1039/C5CP06519D.

Sauerer B, Craddock PR, AlJohani MD, Alsamadony KL, Abdallah W. Fast and accurate shale maturity determination by Raman spectroscopy measurement with minimal sample preparation. Int J Coal Geol. 2017;173:150-7. https://doi.org/10.1016/j. coal.2017.02.008.

Schito A, Corrado S, Aldega L, Grigo D. Overcoming pitfalls of vitrinite reflectance measurements in the assessment of thermal maturity: the case history of the lower Congo basin. Mar Pet Geol. 2016;74:59-70. https://doi.org/10.1016/j.marpetgeo.2016.04.002.

Schito A, Romano C, Corrado S, Grigo D, Poe B. Diagenetic thermal evolution of organic matter by Raman spectroscopy. Org Geochem. 2017;106:57-67. https://doi.org/10.1016/j.orggeochem .2016.12.006.

Schmidt JL, Hinrichs R, Araujo CV. Maturity estimation of phytoclasts in strew mounts by micro-Raman spectroscopy. Int J Coal Geol. 2017;173:1-8. https://doi.org/10.1016/j.coal.2017.02.003.

Snowdon LR. Pyrolysis $T_{\max }$ suppression: documentation and amelioration. AAPG Bull. 1995;79(9):1337-48. https://doi. org/10.1306/7834D4C2-1721-11D7-8645000102C1865D.

Spötl C, Houseknecht DW, Jaques RC. Kerogen maturation and incipient graphitization of hydrocarbon source rocks in the Arkoma Basin, Oklahoma and Arkansas: a combined petrographic and Raman spectrometric study. Org Geochem. 1998;28(9-10):53542. https://doi.org/10.1016/S0146-6380(98)00021-7. 
Standardization Administration of the People's Republic of China (SAC). Rock pyrolysis analysis; GB/T 18602-2012. Beijing: Standards Press of China; 2012 (in Chinese).

Sykes R, Snowdon LR. Guidelines for assessing the petroleum potential of coaly source rocks using pyrolysis. Org Geochem. 2002;33(12):1441-55. https://doi.org/10.1016/S0146 $-6380(02) 00183-3$.

SY/T 5124-2012. Method of determining microscopically the reflectance of vitrinite of sedimentary rock. Published by National Energy Bureau of China; 2012, 10 pp (in Chinese).

Taylor GH, Teichmüller M, Davis ACFK, Diessel CFK, Littke R, Robert P. Organic petrology. Berlin-Stuttgart: Borntraeger; 1998. p. 704.

Tissot BP. Recent advances in petroleum geochemistry applied to hydrocarbon exploration. AAPG Bull. 1984;68(5):545-63. https ://doi.org/10.1306/AD461336-16F7-11D7-8645000102C1865D.

Tuinstra F, Koenig JL. Raman spectrum of graphite. J Chem Phys. 1970;53:1126-30. https://doi.org/10.1063/1.1674108.
Wilkins RW, Boudou R, Sherwood N, Xiao X. Thermal maturity evaluation from inertinites by Raman spectroscopy: the 'RaMM' technique. Int J Coal Geol. 2014;128:143-52. https://doi. org/10.1016/j.coal.2014.03.006.

Wilkins RW, Wang M, Gan H, Li Z. A RaMM study of thermal maturity of dispersed organic matter in marine source rocks. Int J Coal Geol. 2015;150:252-64. https://doi.org/10.1016/j. coal.2015.09.007.

Xie Q, Guan S, Jiao D, Geng H. Relationship between components of inclusion and hydrocarbon accumulation in the Yunlong Depression, Chuxiong Basin. Pet Sci. 2008;5(4):314-21. https://doi. org/10.1007/s12182-008-0053-x.

Zhou Q, Xiao X, Pan L, Tian H. The relationship between microRaman spectral parameters and reflectance of solid bitumen. Int J Coal Geol. 2014;121:19-25. https://doi.org/10.1016/j. coal.2013.10.013. 